\title{
To the problem of selection on intrabreed heterosis
}

\author{
M.I. MONOYENKOV
}

Ivanovo Agricultural Institute, Ivanovo, U.S.S.R.

\begin{abstract}
The use of inbreeding in mating of inbred parents resulted in consolidation and differentiation of animals according to their hereditary qualities, which promoted the manifestation of intrabreed heterosis in milk-yield and fat content in $F_{1}$ and heterosis consolidation and development in $F_{2}$.

The heterosis manifestation is influenced by the quality and position of the common ancestor in pedigree, by selection of parents and other factors. Due to these factors inbreeding has become a method of control and increase of selection efficiency.
\end{abstract}

\section{Efficiency of heterogenous selection in the improvement of cattle breed}

\author{
A.S. VSYAKIKH, G.M. ALEXANDROVA
}

All-Union Agricultural Institute for Education by Correspondance, Moscow, U.S.S.R.

The paper presents the data on the results of heterogenous selection in improving the cattle breeds. The milk yield as a result of matings between Red Gorbatovskaya and Red Danish animals was as follows : for the first lactation $-3.348 \mathrm{~kg}$, for the second one $-3.934 \mathrm{~kg}$, and for the third one $-4.035 \mathrm{~kg}$, the fat content being from $4 \mathrm{p} .100$ to $4.04 \mathrm{p} .100$ which exceeds the yield of the contemporaries by $839 \mathrm{~kg}, 1.041 \mathrm{~kg}$ and $1.272 \mathrm{~kg}$ respectively, the fat content being the same. As a result of the matings between the animals of the Kostromskaya breed and the $S$ wiss one (of the American origin) the milk yield of $F_{1}$ cows for the first lactation amounted to $4.127 \mathrm{~kg}$ and was 522 higher than that of the contemporaries.

\section{Results of alternate crossing of Polish black and white cattle with Holstein, Friesian and Finnish Ayrshire bulls}

\author{
Z. PASIERBSKI \\ Institute of Animal Husbandry, Krakov, Poland
}

Crossing of local Black and White cattle with Holstein-Friesian (hf) and Ayrshire (ay)bulls proved the usefulness of both breeds to create a type of cattle that is characterized by high productive parameters. Up to the present it was obtained $F_{1}$. Fattening bulls $F_{1}$ ay had worse daily weight gain than $F, h f$ by 11 p. 100 , worse carcass dressing by 4.2 p. 100 , but better feed utilization. During 305 days of lactation heifers $F_{1}$ ay produced $3.776 \mathrm{~kg}$ of milk containing $3.96 \mathrm{p} .100$ of fat, 3.19 p. 100 of protein and 12.5 p. 100 of dry matter, while $F_{1} h f 4.002 ; 3.67 ; 3.05$ and 11.72 respectively. 